\title{
Analisis terhadap Sertifikasi Minyak Kelapa Sawit Berkelanjutan sebagai Instrumen Penaatan Hukum LINGKUNGAN
}

\author{
Oleh: Fadhil Muhammad Indrapraja ${ }^{1}$
}

\begin{abstract}
Abstrak
Minyak kelapa sawit merupakan komoditas yang digunakan untuk berbagai macam produk, seperti minyak goreng, margarin, kosmetik, dan bahan bakar hayati. Didorong oleh tuntutan global, permintaan pasar terhadap minyak kelapa sawit di berbagai belahan dunia membuat kelapa sawit menjadi sumber minyak nabati terbesar. Perkembangan produksi minyak kelapa sawit tersebut memberikan dampak ekonomi yang positif. Kendati demikian, perkembangan produksi minyak kelapa sawit juga berdampak negatif terhadap lingkungan dan kehidupan sosial. Salah satu upaya yang dilakukan untuk mengantisipasi dampak negatif tersebut adalah dengan menerapkan standar minyak kelapa sawit berkelanjutan melalui sistem sertifikasi. Penelitian ini mencoba untuk mengkaji secara normatif tiga sistem sertifikasi minyak kelapa sawit berkelanjutan, yaitu Sertifikasi Roundtable on Sustainable Palm Oil, Sertifikasi Indonesian Sustainable Palm Oil, dan Sertifikasi Malaysian Sustainable Palm Oil sebagai instrumen penaatan hukum lingkungan. Hasil penelitian dalam tulisan ini menunjukkan bahwa ketiga sistem sertifikasi tersebut belum optimal sebagai instrumen penaatan hukum lingkungan. Untuk itu, ketiga sistem sertifikasi tersebut perlu disempurnakan.
\end{abstract}

Kata kunci: Berkelanjutan, minyak kelapa sawit, sertifikasi lingkungan

1 Penulis adalah lulusan hukum lingkungan dari Fakultas Hukum Universitas Indonesia. Penulis dapat dihubungi di surel fadhilindrapraja@gmail.com. 


\begin{abstract}
Palm oil is an important commodity that is used for various products, such as cooking oil, margarine, cosmetics, and biofuel. Driven by global demands, market demand for palm oil in many parts of the world makes oil palm the highest yielding source of vegetable oil. The expansion of palm oil production plays an important role in providing positive economic impact. Nevertheless, the expansion of palm oil production also has negative impact socially and environmentally. One of the efforts needed to achieve sustainable palm oil production is to apply sustainable palm oil standards through a certification system. This thesis tries to study normatively three certification systems of palm oil, namely Roundtable on Sustainable Palm Oil Certification, Indonesian Sustainable Palm Oil Certification, and Malaysian Sustainable Palm Oil Certification as an environmental law compliance instrument. The result of this research shows us that the three certification systems are not yet optimal. Therefore, that three certification systems need to be revised.

Keywords: environmental certification, palm oil, sustainability

\section{Pendahuluan}

Pada awal keberadaannya di Indonesia, kelapa sawit hanyalah tumbuhan hias yang menjadi koleksi di Kebun Raya Bogor. Kelapa sawit baru dibudidayakan dalam bentuk usaha perkebunan pada tahun 1875 oleh perusahaan asal Belanda yang bernama Deli Maatschappij. ${ }^{2}$ Pada saat itu, produksi kelapa sawit di Indonesia cukup memuaskan dan memiliki kualitas lebih baik daripada hasil produksi di Afrika Barat, habitat asal kelapa sawit. ${ }^{3}$ Sejak saat itu, industri kelapa sawit nasional terus berkembang hingga menjadikan tanaman kelapa sawit menjadi sumber minyak nabati terbesar di dunia. Dalam hal ini, sejak tahun 2006 Indonesia berhasil mengungguli dominasi Malaysia sebagai negara produsen minyak kelapa sawit terbesar di dunia. Padahal, Malaysia telah lebih dulu mengembangkan komoditas kelapa sawit.
\end{abstract}

2 Bungaran Saragih, Mitos versus Fakta Industri Minyak Sawit Indonesia dalam Isu Sosial, Ekonomi dan Lingkungan Global, ed. 2 (Bogor: PASPI, 2016), hlm. 1.

3 Ibid. 
Sebagai produsen minyak kelapa sawit terbesar di dunia, industri minyak kelapa sawit Indonesia berperan strategis bagi perekonomian nasional dan global. Merujuk pada produksi minyak kelapa sawit Indonesia pada tahun 2016, Menteri Keuangan Republik Indonesia, Sri Mulyani mengatakan “kontribusi ekspor sawit mencapai US\$ 17,8 miliar atau senilai Rp. 231,4 triliun dengan penyerapan tenaga kerja mencapai 5,6 juta orang, yang berarti industri sawit merupakan sektor penting untuk dijaga keberlangsungannya." ${ }^{4}$ Selain itu, menurut Gabungan Pengusaha Kelapa Sawit Indonesia (GAPKI) pengembangan industri produksi minyak kelapa sawit mayoritas dilakukan di wilayah pedesaan, sehingga berdampak positif dalam mendorong pembangunan wilayah pedesaan. Hal ini merupakan upaya yang tepat untuk mengurangi tingkat kemiskinan penduduk Indonesia karena mayoritas penduduk miskin di Indonesia berada di wilayah pedesaan. Hingga tahun 2013 paling tidak terdapat lima puluh kawasan pedesaan terbelakang atau terisolir telah berkembang menjadi kawasan pertumbuhan baru dengan basis sentra produksi minyak kelapa sawit. ${ }^{5}$

Kendati berkontribusi positif bagi perekonomian, perkembangan produksi kelapa sawit juga berdampak negatif bagi lingkungan dan kehidupan sosial. Berbagai investigasi menemukan bukti-bukti yang menunjukkan permasalahanpermasalahan lingkungan dan sosial yang disebabkan oleh aktivitas industri minyak kelapa sawit. Menurut catatan Forest Watch Indonesia, dalam periode 2009 - 2013 Indonesia kehilangan hutan alam seluas 515,9 ribu hektar akibat alih fungsi hutan menjadi perkebunan kelapa sawit. ${ }^{6}$ Deforestasi yang terjadi menimbulkan berbagai permasalahan lingkungan, seperti hilangnya keanekaragaman hayati, banjir, kekeringan, longsor, dan perubahan iklim.

Ekspansi perkebunan kelapa sawit juga dilakukan di lahan gambut. Pada tahun 2014 terdapat 429.587 hektar tutupan hutan di lahan gambut yang sudah

4 Tempo, "Sri Mulyani Minta Industri Sawit Sumbang Pendapatan Negara," https://m. tempo.co/read/news/2017/02/02/090842383/sri-mulyani-minta-industri-sawit-sumbangpendapatan-negara, diakses tanggal 27 Maret 2017.

5 Gabungan Pengusaha Kelapa Sawit Indonesia, “Industri Minyak Sawit Indonesia Merupakan Industri Strategis Nasional," https://gapki.id/industri-minyak-sawit-merupakan-industristrategis-nasional/\#more-1860, diakses tanggal 31 Maret 2017.

6 Forest Watch Indonesia, Enam Tahun ISPO Kajian Terkait Penguatan Instrumen ISPO dalam Merespon Dampak-dampak Negatif Seperti Deforestasi, Kerusakan Ekosistem Gambut, Kebakaran Hutan dan Lahan, serta Konflik Tenurial (Bogor: Forest Watch Indonesia, 2017), hlm. 33. 
dibebani izin pengelolaan perkebunan kelapa sawit. ${ }^{7}$ Penanaman kelapa sawit di lahan gambut mengakibatkan lahan gambut kehilangan fungsinya untuk menyimpan karbon dioksida dan tempat berkembangnya berbagai macam flora dan fauna.

Kemudian, merujuk laporan yang dibuat oleh Amnesty International terdapat bukti keterlibatan pekerja anak di perkebunan kelapa sawit yang dimiliki oleh dua anak perusahaan Wilmar (PT. Daya Labuhan Indah dan PT. Milano) dan tiga pemasok Wilmar (PT Abdi Budi Mulia, PT Sarana Prima Multi Niaga, dan PT Hamparan). ${ }^{8}$ Padahal, pekerjaan di perkebunan kelapa sawit tergolong berat dan beresiko terhadap kesehatan anak. Paling tidak terdapat dua undangundang yang melarang anak untuk bekerja berat, yakni Undang-undang Nomor 35 Tahun 2014 tentang Perubahan atas Undang-undang Nomor 23 Tahun 2002 tentang Perlindungan Anak dan Undang-undang Nomor 13 Tahun 2003 tentang Ketenagakerjaan.

Permasalahan-permasalahan tersebut menjadi alasan dari munculnya beragam kampanye untuk mendorong masyarakat menghentikan konsumsi produk-produk minyak kelapa sawit. Pada bulan Juni tahun 2015, Menteri Ekologi Prancis, Segolene Royal menyeru masyarakat untuk menghentikan konsumsi produk Nutella karena mengandung minyak kelapa sawit. Ia mengatakan "we have to replant a lot of trees because there is massive deforestation that also leads to global warming. We should stop eating Nutella, for example, because it's made with palm oil. ${ }^{9}$

Tidak terbatas pada seruan tersebut, Pemerintah Prancis juga merumuskan kebijakan pajak progresif impor minyak kelapa sawit. Pada tanggal 4 April 2017, Parlemen Uni Eropa juga telah mengesahkan European Parliament Resolution on Palm Oil and Deforestation of Rainforests ${ }^{10}$ yang dalam mukadimahnya mengakui bahwa industri produksi minyak kelapa sawit merupakan penyebab berbagai masalah lingkungan dan pelanggaran hak asasi manusia. Atas dasar maraknya permasalahan yang mucul serta kewajiban untuk merespon kampanye-kampanye

$7 \quad$ Ibid., Hlm. 39.

8 Amnesty International, Skandal Besar Minyak Kelapa Sawit: Pelanggaran Ketenagakerjaan di Belakang Nama-nama Merek Besar (London: Amnesty International Ltd., 2016), hlm. 5.

9 Justin Worland, "Why The French Ecology Minister Just Said We Should Stop Eating Nutella," http://time.com/3924050/french-ecology-minister-nutella/, diakses tanggal 26 Mei 2017.

10 Parlemen Uni Eropa, Resolution 2222 (2016), 4 April 2017, butir 47. 
negatif terhadap minyak kelapa sawit muncul kebutuhan untuk memastikan penyelenggaraan produksi minyak kelapa sawit berkelanjutan. Kebutuhan tersebut berupaya dipenuhi dengan menerapkan sistem sertifikasi. Sistem sertifikasi ini diharapkan dapat mendorong pelaku industri minyak kelapa sawit untuk menerapkan prinsip dan kriteria produksi minyak kelapa sawit yang dapat menyerasikan kepentingan ekonomi, lingkungan, dan sosial.

Terdapat tiga sistem sertifikasi minyak kelapa sawit berkelanjutan, yakni Sertifikasi Roundtable on Sustainable Palm Oil (RSPO), Sertifikasi Indonesian Sustainable Palm Oil (ISPO), dan Sertifikasi Malaysian Sustainable Palm Oil (MSPO). Dalam perkembangannya, ketiga sistem sertifikasi ini dianggap belum mampu untuk memastikan penyelenggaraan produksi minyak kelapa sawit berkelanjutan. Hal ini terbukti dengan masih ditemukannya permasalahan lingkungan dan sosial yang disebabkan aktivitas industri minyak kelapa sawit.

Dalam European Parliament Resolution on Palm Oil and Deforestation of Rainforests disebutkan bahwa salah satu rekomendasi yang termuat dalam resolusi tersebut ialah meminta Komisi Uni Eropa untuk meningkatkan penelusuran (traceability) dari produk minyak kelapa sawit yang diimpor oleh Uni Eropa, hingga sistem sertifikasi tunggal produksi minyak kelapa sawit diterapkan. ${ }^{11}$ Parlemen Uni Eropa meminta Komisi Uni Eropa untuk membentuk sistem sertifikasi tunggal minyak kelapa sawit yang dapat memastikan bahwa produk minyak kelapa sawit yang diimpor oleh Uni Eropa telah diproduksi secara berkelanjutan. Kondisi ini mengindikasikan adanya keraguan pada sistem Sertifikasi RSPO, Sertifikasi ISPO, dan Sertifikasi MSPO.

Berdasarkan persoalan tersebut, tulisan ini akan menganalisis ketiga sistem sertifikasi minyak kelapa sawit berkelanjutan sebagai instrumen penaatan hukum lingkungan. Analisis akan didahului dengan latar belakang sertifikasi minyak kelapa sawit. Kemudian, akan dipaparkan secara singkat mengenai munculnya kesadaran akan lingkungan dan perkembangan instrumen penaatan hukum lingkungan. Paparan ini bertujuan untuk memudahkan pembaca memahami konsep sertifikasi lingkungan sebagai instrumen penaatan hukum lingkungan. Setelah itu, akan diulas konsep sertifikasi lingkungan dan penerapannya pada industri minyak

$11 \quad$ Ibid., butir 47. 
kelapa sawit berkelanjutan. Tulisan ini akan ditutup dengan usulan-usulan yang terkait dengan upaya untuk menyempurnakan sertifikasi minyak kelapa sawit berkelanjutan sebagai instrumen penaatan hukum lingkungan.

\section{Kesadaran Lingkungan dan Perkembangan Instrumen Penaatan Hukum Lingkungan}

Sebelum masuk pada pembahasan inti, penting untuk mengetahui awal mula lahirnya kesadaran lingkungan yang kemudian diikuti oleh perkembangan instrumen-instrumen penaatan hukum lingkungan.

Perhatian negara-negara di dunia terhadap isu lingkungan didorong oleh ketidakteraturan alam yang semakin marak menghadirkan bencana. Ketidakteraturan tersebut merupakan akibat ulah manusia yang memanfaatkan lingkungan secara serampangan. Kondisi ini tidak terlepas dari perubahan pola kehidupan manusia yang mulanya bersifat tradisional menjadi mekanisasi paska era revolusi industri. Dalam ilmu ekologi, manusia adalah satu kesatuan yang terpadu dengan lingkungannya. ${ }^{12}$ Kesatuan yang terpadu dapat dimaknai bahwa manusia dan lingkungan memiliki hubungan saling membutuhkan. Ketika manusia mencoba untuk menguasai lingkungan, maka lingkungan akan menghadirkan bencana bagi kehidupan manusia itu sendiri.

Kesadaran dan kepentingan untuk menentukan tata susunan lingkungan di tengah kebutuhan pembangunan menuntut hadirnya hukum yang mengatur tatanan lingkungan. Dalam perkembangannya, paling tidak terdapat tiga pendekatan yang dilakukan untuk mencapai penaatan hukum lingkungan, yakni melalui pendekatan atur dan awasi (command and control), instrumen ekonomi, dan penaatan sukarela.

\section{a. Pendekatan Atur dan Awasi}

Pendekatan ini dapat dikatakan sebagai upaya penaatan hukum lingkungan generasi pertama. Pada awalnya, masyarakat mempunyai akses bebas pada sumber daya alam. Masyarakat juga berpandangan bahwa jumlah sumber daya

12 N.H.T. Siahaan, Hukum Lingkungan dan Ekologi Pembangunan, (Jakarta: Erlangga, 2004), hlm. 43. 
alam tidak terbatas, sehingga setiap individu berusaha meraih keuntungan sebanyak-banyaknya. ${ }^{13}$ Peningkatan kuantitas manusia beserta kebutuhannya mengakibatkan pemanfaatan sumber daya alam dilakukan secara berlebihan, sehingga melampaui kemampuan sumber daya alam yang kemudian menyebabkan kerusakan pada sumber daya alam. ${ }^{14}$ Berdasarkan kondisi tersebut, diperlukan pembatasan terhadap akses masyarakat untuk menggunakan sumber daya alam. Pembatasan tersebut diwujudkan melalui tindakan pemerintah untuk mengatur dan mengawasi. Pendekatan ini menggunakan peraturan-peraturan administrasi yang ditujukan sebagai sistem kontrol. ${ }^{15}$ Regulator menyusun sebuah kerangka bagi kegiatan-kegiatan dengan maksud untuk mengondisikan, mengawasi, serta menetapkan aturan bagi kegiatan-kegiatan tersebut. ${ }^{16}$

Pendekatan atur dan awasi berupaya untuk menekan egoisme dan mendorong setiap orang untuk berkelakuan lebih ramah lingkungan dengan ancaman sanksi tindakan hukum. ${ }^{17}$ Pendekatan ini sangat mengandalkan paksaan, sehingga memerlukan peran pemerintah yang dominan. Dalam hal ini, pemerintah perlu menentukan target atau batasan emisi yang harus dicapai, prosedur dan cara seperti apa yang harus diambil, bahkan teknologi apa yang harus digunakan oleh individu dalam pemanfaatan lingkungan. ${ }^{18}$ Setelah menentukan target atau batas yang harus dicapai, pemerintah mengawasi dan menegakkan peraturan yang sudah ditetapkan.

Kendati marak digunakan sebagai upaya penaatan hukum lingkungan, namun pendekatan ini dinilai memiliki beberapa kelemahan. Otto Soemarwoto dalam bukunya yang berjudul Atur Diri Sendiri: Paradigma Baru Pengelolaan Lingkungan Hidup mengatakan:

13 Otto Soemarwoto, Atur Diri Sendiri: Paradigma Baru Pengelolaan Lingkungan Hidup, (Yogyakarta: Gadjah Mada University Press, 2004), hlm. 94-95.

14 Ibid., hlm. 95.

15 Andri G. Wibisana, "Penaatan Hukum Lingkungan: Command and Control, Instrumen Ekonomi, dan Penaatan Sukarela," draft Buku Hukum Lingkungan Indonesia (Januari 2016), hlm. 3.

16 Ibid.

17 Soemarwoto, Atur Diri Sendiri: Paradigma Baru Pengelolaan Lingkungan Hidup, hlm. 93

18 Andri G. Wibisana, "Pencegahan dan Pengendalian Pencemaran dan Kerusakan Lingkungan," dalam Hukum Lingkungan Teori, Legislasi dan Studi Kasus, eds. Laode M. Syarif dan Andri G. Wibisana [s.l.: s.n., s.a.], hlm. 262-263. 


\begin{abstract}
“Tindakan itu berlawanan dengan egoisme yang berakar di dalam diri manusia, orang selalu berusaha untuk menghindari tindakan yang merugikan dirinya itu. Cara yang termudah ialah untuk diam-diam melanggarnya dengan harapan tidak akan diketahui oleh pihak yang berwenang." 19
\end{abstract}

Akibatnya muncul penolakan terhadap aturan-aturan yang ditetapkan pemerintah. Pelaku usaha cenderung berupaya untuk menghindari aturan-aturan tersebut dengan beragam cara. Hal inilah yang menjadi kritik terbesar pendekatan atur dan awasi.

Kemudian, pendekatan ini juga dinilai tidak efektif dan efisien. Pendekatan atur dan awasi menuntut pemerintah atau regulator untuk memiliki pengetahuan yang komprehensif dan akurat tentang cara kerja dan kapasitas industri. ${ }^{20}$ Di lain sisi, terdapat perbedaan pengetahuan antara pemerintah dan pelaku usaha. ${ }^{21}$ Ketika suatu standar sudah ditetapkan, maka pelaku industri hanya dapat terpaku terhadap apa-apa yang sudah ditetapkan tanpa bisa menggunakan cara-cara lain yang lebih efektif dan efisien. ${ }^{22}$ Hal ini disebabkan pendekatan ini tidak dapat beradaptasi dengan baik terhadap perkembangan atau perubahan populasi, teknologi, dan aktivitas ekonomi yang memengaruhi kebutuhan atau kemampuan pelaku usaha dan perkembangan masalah-masalah lingkungan. ${ }^{23}$

Kemudian, pendekatan ini tidak memberikan insentif bagi pelaku industri atau usaha untuk mencapai penaatan di atas standar (beyond minimum standards). ${ }^{24}$ Melakukan penaatan di atas standar memerlukan biaya tambahan, tidak adanya insentif terhadap hal tersebut berlawanan dengan tujuan setiap pelaku usaha untuk memperoleh keuntungan sebanyak-banyaknya. Hal ini mengakibatkan pelaku usaha beranggapan sepanjang emisi yang dikeluarkan tidak melebihi batas, hal itu

19 Soemarwoto, Atur Diri Sendiri: Paradigma Baru Pengelolaan Lingkungan Hidup, hlm. 98.

20 Neil Gunningham, Darren Sinclair, dan kontribusi dari Peter Grabosky, "Instrument for Environmental Protection" dalam Smart Regulation Designing Environmental Policy, (Oxford: Oxford University Press, 2004), hlm. 44.

21 Ibid.

22 Pemerintah menentukan secara spesifik teknologi atau performa yang harus digunakan oleh pelaku usaha, sehingga menghambat pengadopsian teknologi baru.

23 Alvin L. Alm, "A Need For New Approaches: Command-and-control is no longer a cure-all," EPA Journal 18 (May/June 1992), hlm. 7.

24 Ibid., hlm. 45. 
sudah dianggap cukup, sehingga tidak perlu lagi mengurangi emisi. ${ }^{25}$

Kekurangan lainnya ialah pendekatan atur dan awasi sangat birokratis, mahal, serta rawan manipulasi. Pejabat hanya bisa bertindak dalam ruang lingkup apa-apa yang sudah diatur, sehingga para pejabat cenderung mengedepankan kepentingan birokrasi daripada tercapainya perlindungan lingkungan hidup yang baik. ${ }^{26}$ Mengingat luas dan banyaknya objek yang diawasi, untuk mencapai pengawasan dan penegakan hukum yang optimal tentu pendekatan ini memerlukan biaya besar. Terakhir, pendekatan ini juga rawan manipulasi politik. ${ }^{27} \mathrm{Hal}$ ini diindikasikan dengan ditemukannya peraturan yang dibentuk sebatas untuk mengakomodasi kepnggaentingan pihak-pihak tertentu dan permasalahan lain yang terkait dengan penegakan hukum.

\section{b. Instrumen Ekonomi}

Instrumen ekonomi lahir dari gagasan yang dikemukakan ahli-ahli ekonomi, seperti Arthur C. Pigou dan Ronald Coase. Setiap akan mengambil suatu keputusan, manusia selalu mempertimbangkan potensi untung dan rugi yang mungkin didapatkannya. Terkait hal ini, Mas Achmad Santosa menyebutkan bahwa "pihak yang bertanggung jawab atas sebuah kegiatan yang berdampak penting terhadap lingkungan, secara rasional menghitung terlebih dahulu sejauh mana melaksanakan penaatan akan mendatangkan keuntungan secara ekonomis." 28 Hal inilah yang menjadi alasan penerapan instrumen ekonomi sebagai instrumen penaatan hukum lingkungan. Berbeda dengan pendekatan atur dan awasi yang mengandalkan paksaan, instrumen ekonomi mengandalkan insentif dan disinsentif.

Instrumen ekonomi berkaitan erat dengan prinsip pencemar membayar (polluter pays principle). ${ }^{29}$ Perwujudan prinsip pencemar membayar melalui instrumen ekonomi dapat dilakukan dalam bentuk pajak lingkungan, sistem jaminan uang

25 Wibisana, "Penaatan Hukum Lingkungan: Command and Control, Instrumen Ekonomi, dan Penaatan Sukarela," hlm. 9.

26 Soemarwoto, Atur Diri Sendiri: Paradigma Baru Pengelolaan Lingkungan Hidup, hlm. 105.

27 Gunningham, Darren Sinclair, dan kontribusi dari Peter Grabosky, "Instrument for Environmental Protection," hlm. 46.

28 Mas Achmad Santosa, Good Governance \& Hukum Lingkungan, (Jakarta: ICEL, 2001), hlm. 234.

29 Andri Gunawan Wibisana, "Penaatan Hukum Lingkungan: Command and Control, Instrumen Ekonomi, dan Penaatan Sukarela," hlm. 9. 
(deposit-refund system), dan izin yang dapat diperjualbelikan (tradeable permits). Selain bentuk-bentuk tersebut, dalam perkembangannya terdapat pula bentuk insentif pemberian subsidi bagi pelaku usaha untuk melakukan upaya-upaya ramah lingkungan. Dalam hal ini, instrumen ekonomi juga membutuhkan peran yang dominan dari pemerintah, mulai dari pengaturan, perizinan (tradeable permits), penetapan harga (terutama dalam penetapan tax rate), hingga pengawasan..$^{30}$

Kendati dinilai memberikan dampak positif bagi upaya penaatan hukum lingkungan, instrumen ekonomi juga memiliki beberapa kelemahan. Instrumen ekonomi ini seolah memberikan hak kepada pelaku usaha untuk mencemari atau merusak lingkungan dengan membayar sejumlah dana. ${ }^{31}$ Kondisi tersebut ditambah dengan sulitnya regulator untuk menentukan dengan tepat besaran dan kegunaan insentif atau disinsentif yang akan didapat oleh pelaku usaha dari perilakunya terhadap lingkungan. Kemudian, terdapat persoalaan terkait jumlah pungutan pemerintah. Jika pungutan pemerintah lebih kecil daripada dana yang harus dikeluarkan pelaku usaha untuk berperilaku ramah lingkungan atau jumlah dana yang dipungut tidak sebanding dengan kebutuhan dana untuk pemulihan lingkungan, maka instrumen ini tidak optimal bagi upaya pengendalian lingkungan. Terakhir, instrumen ekonomi juga membutuhkan peran yang dominan dari pemerintah, mulai dari pengaturan, perizinan (tradeable permits), penetapan harga (terutama dalam penetapan tax rate), hingga pengawasan. ${ }^{32} \mathrm{Hal}$ ini mengakibatkan instrumen ekonomi memiliki kelemahan-kelemahan yang serupa dengan pendekatan command and control yang bersifat birokratis, mahal, dan rawan manipulasi.

\section{c. Penaatan Sukarela}

Penaatan sukarela merupakan penaatan hukum lingkungan generasi ketiga. Berbeda dengan dua generasi sebelumnya, penaatan sukarela memberikan pilihan bagi individu atau pelaku usaha untuk secara sukarela melakukan penaatan hukum lingkungan. Merujuk pada pendapat Oates dan Baumol sebagaimana dikutip oleh

$30 \quad$ Ibid., hlm. 17.

31 Dalam penerapan instrumen tradeable permit, pemerintah memberikan kuota untuk mencemari lingkungan kepada pelaku usaha.

32 Wibisana, "Penaatan Hukum Lingkungan: Command and Control, Instrumen Ekonomi, dan Penaatan Sukarela," hlm. 17. 
Andri G. Wibisana, penaatan sukarela didasarkan pada ketiadaan penegakan hukum, sehingga penaatan menjadi keputusan individual yang bersifat sukarela. ${ }^{33}$ Pada penaatan sukarela ini, inisiatif pada umumnya berasal dari pemerintah, namun berbeda dengan penaatan command and control dan penaatan ekonomi, pada penaatan sukarela peran pemerintah sangat terbatas sebagai pendorong atau fasilitator. $^{34}$

Karp dan Gaulding sebagaimana dikutip Naoufel Mzoughi dan Gilles Grolleau, menyebutkan "sebagai upaya membentuk perilaku manusia, penaatan sukarela didasarkan adanya etik dan tanggung jawab sosial." ${ }^{35}$ Kemudian, Peter Borkey, Matthieu Glachant, dan Francois Leveque dalam laporannya yang berjudul Voluntary Approaches for Environmental Policy in OEDC Countries: An Assessment menyebutkan:

“Voluntary Approaches have been developed by policymakers and industrialists to provide pragmatic responses to new policy problems, namely the need for more flexible ways to achieve sustainability, and the need to take into account the rising concerns about industrial competitiveness and the increasing administrative burden after three decades of command and control based environmental policy." 36

Dari penjelasan tersebut, dapat diketahui bahwa penerapan pendekatan penaatan sukarela diharapkan dapat mengurangi peran pemerintah dan mendorong partisipasi dari aktor-aktor non pemerintah, khususnya pelaku industri. Atas dasar itu, berbagai hambatan seperti upaya penaatan yang tidak efisien, mahal, dan rawan manipulasi diharapkan dapat dihindari. Sebaliknya, pelaku usaha diharapkan dapat mengembangkan inovasi-inovasi untuk pengendalian lingkungan dan mencapai upaya penaatan yang lebih optimal berdasarkan adanya motivasi diri sendiri untuk berperilaku ramah lingkungan. Motivasi tersebut diidentifikasi berasal dari tiga aspek, yakni motivasi etik, motivasi kompetitif, dan motivasi

33 Ibid., hlm. 16-17.

34 Ibid., hlm. 18.

35 Naoufel Mzoughidan Gilles Grolleau, “Voluntary Instrument for Environmental Management: a Critical Review of Definitions," (makalah disampaikan pada Annual Conference of Canadian Economic Association, Ottawa, 29 Mei-1 Juni 2003), hlm. 5.

36 Peter Borkey, Matthieu Glachant, dan Francois Leveque, "Voluntary Approaches for Environmental Policy in OEDC Countries: An Assessment," Centre d'economie Industrielle, hlm. 8 
relasi. ${ }^{37}$ Motivasi etik berkaitan dengan tanggung jawab lingkungan (ekologi) yang dibebankan kepada pelaku usaha, motivasi kompetitif muncul atas kepentingan untuk memperoleh keuntungan dengan praktik-praktik yang berkelanjutan, dan motivasi relasi bertujuan untuk mencapai legitimasi dan hubungan yang lebih baik dengan para pemangku kepentingan. ${ }^{38}$

Dalam pelaksanaannya, diketahui bahwa nilai etik dan tanggung jawab sosial sebagai dasar pendekatan penaatan sukarela tidak cukup untuk memastikan pelaku industri untuk berperilaku ramah lingkungan. Dalam hal ini dibutuhkan faktor-faktor eksternal lain, seperti dorongan masyarakat untuk berperilaku ramah lingkungan. Menurut Dirk Schmelzer dalam buku yang ditulis oleh Al Iannuzzi yang berjudul Industry Self-Regulation and Voluntary Environmental Compliance disebutkan "companies want to be recognized as socially responsible by customers, employees, and neighbors." ${ }^{39}$ Dalam hal ini, pelaku usaha secara sukarela melakukan upaya penaatan demi memperoleh reputasi yang baik. Pada kondisi tertentu, pelaku usaha secara sukarela melakukan penaatan atau bergabung dengan program-program sukarela atas adanya opsi penaatan yang lebih fleksibel. Terkait hal ini Robert Gibson berpendapat:

"If firms can pick the methods that best fit their operations, they will incur fewer expenses and will implement the programs more quickly. The cost savings that result from preventing pollution are also a motivating factor in proactively eliminating pollution." 40

Sebagai contoh, pada program sertifikasi ISO-14001 yang berisikan standarstandar sistem manajemen lingkungan, tidak ada kewajiban bagi perusahaan atau institusi untuk mendapatkan sertifikat ISO-14001. Perusahaan atau institusi secara sukarela berupaya untuk mendapatkan sertifikat ISO-14001 berdasarkan adanya kepentingan untuk meningkatkan reputasi atau nilai dagang perusahaan atau institusi yang bersangkutan. Demi mendapatkan kepercayaan masyarakat, pada

37 Javier Gonzalez dan Oscar Gonzalez, "An Analysis of the Relationship Between Environmental Motivations and ISO14001 Certification," British Journal of Management 16 (Juni 2005), hlm. 136.

38 Ibid.

39 Alphonse Iannuzzi, Jr., Industry Self-Regulation and Voluntary Environmental Compliance, (Washington DC: Lewis Publishers, 2002), hlm. 13-14.

$40 \quad$ Ibid., hlm. 14. 
umumnya standar-standar yang diterapkan lebih berat daripada standar yang ditentukan pemerintah (peraturan perundang-undangan). ${ }^{41}$ Selain itu, menerapkan standar ISO-14001 dianggap dapat meningkatkan efektivitas dan efisiensi kinerja manajemen lingkungan perusahaan. Contoh-contoh lain dari penerapan penaatan sukarela ialah audit lingkungan sukarela dan perjanjian sukarela.

Sama seperti dua pendekatan sebelumnya, penaatan sukarela juga memiliki kelemahan-kelemahan, di antaranya kurangnya transparansi, tidak jelasnya insentif bagi pelaku usaha atau kegiatan, kurangnya kepercayaan publik, maupun kemungkinan adanya persoalan free-rider atau regulatory capture. ${ }^{42}$ Agar persoalan tersebut dapat diselesaikan, Organisation for Economic Co-operation and Development (OECD) sebagaimana dikutip Andri G. Wibisana menyebutkan bahwa terdapat beberapa hal yang harus diperhatikan, yaitu target yang jelas dan transparan, adanya patokan yang dijadikan ukuran untuk membandingkan dengan target yang ingin dicapai, adanya insentif atau disinsentif yang kredibel dari pemerintah, adanya pengawasan yang kredibel, partisipasi pihak ketiga pada saat penentuan target dan monitoring pelaksanaan, adanya ancaman sanksi bagi kegagalan mencapai target, adanya ketentuan terkait penyediaan informasi, dan adanya upaya untuk memastikan bahwa penaatan sukarela tidak memiliki efek persaingan usaha yang tidak sehat. ${ }^{43}$

\section{Sertifikasi Lingkungan sebagai Instrumen Penaatan Hukum Lingkungan Sukarela}

Dalam perkembangannya, salah satu instrumen yang diterapkan untuk mencapai penaatan hukum lingkungan ialah instrumen sertifikasi. Instrumen sertifikasi dipilih untuk mendorong kesukarelaan pelaku usaha agar berupaya mencapai penaatan hukum lingkungan.

41 Soemarwoto, Atur Diri Sendiri: Paradigma Baru Pengelolaan Lingkungan Hidup, hlm. 109.

42 Free-rider atau regulatory capture sebagaimana dimaksud mengacu pada situasi yang mana pemerintah tidak bekerja maksimal atau tidak memiliki kinerja. Terkait hal ini dapat pula terjadi dalam situasi pemerintah yang seyogyanya melindungi kepentingan masyarakat, justru didominasi oleh kepentingan industri (objek yang diatur).

43 Andri Gunawan Wibisana, "Penaatan Hukum Lingkungan: Command and Control, Instrumen Ekonomi, dan Penaatan Sukarela," hlm. 18-19. 
Ditinjau dari definisi dan fungsinyanya, sertifikasi merupakan terjemahan dari kata certification. International Organization for Standardization (ISO) mendefinisikan sertifikasi sebagai " the provision by an independent body of written assurance (a certificate) that the product, service or system in question meets specific requirements." ${ }^{44}$ Terkait dengan fungsinya, sertifikasi dapat bermanfaat untuk menambah kredibilitas suatu produk atau jasa dengan menunjukkan bahwa produk atau jasa tersebut memenuhi harapan konsumen dengan memenuhi standar-standar tertentu. ${ }^{45}$

Dalam kaitannya dengan upaya perlindungan dan pengelolaan lingkungan, sertifikasi lingkungan (environmental certification) pada umumnya merupakan bentuk regulasi yang mendorong perusahaan untuk secara sukarela berperilaku ramah lingkungan dengan memenuhi standar-standar tertentu demi menunjukkan kepada konsumen bahwa kegiatan usahanya telah dilakukan secara berkelanjutan. Sertifikasi lingkungan berkaitan erat dengan sistem label ramah lingkungan yang dikenal dengan istilah eco-labelling. Bagi pelaku usaha yang memperoleh sertifikat lingkungan, maka ia dapat menggunakan label ramah lingkungan yang disediakan oleh penyelenggara sertifikasi pada produknya.

Motivasi pelaku usaha untuk memperoleh sertifikat lingkungan sebagaimana sudah disinggung sebelumnya dapat diidentifikasi ke dalam tiga aspek, yakni motivasi etik, motivasi kompetitif, dan motivasi relasi. ${ }^{46}$ Motivasi etik berkaitan dengan tanggung jawab lingkungan (ekologi) yang dibebankan kepada pelaku usaha, motivasi kompetitif muncul atas kepentingan untuk memperoleh keuntungan dengan praktik-praktik yang berkelanjutan, dan motivasi relasi bertujuan untuk mencapai legitimasi dan hubungan yang lebih baik dengan para pemangku kepentingan. ${ }^{47}$

Salah satu fungsi utama sertifikasi ialah meningkatkan nilai dagang suatu kegiatan, produk atau jasa suatu perusahaan atau institusi. Demi mendapatkan kepercayaan dari masyarakat, maka standar-standar yang dimuat pada umumnya

44 International Organization for Standardization, "Certification and Conformity Certification," https://www.iso.org/certification.html, diakses tanggal 12 April 2017.

45 Ibid.

46 Javier Gonzalez dan Oscar Gonzalez, "An Analysis of the Relationship Between Environmental Motivations and ISO14001 Certification," British Journal of Management 16 (Juni 2005), hlm. 136.

47 Ibid. 
lebih tinggi dari standar-standar yang ditentukan peraturan perundang-undangan (beyond compliance). ${ }^{48}$ Pada kondisi inilah sistem sertifikasi dapat optimal dalam meningkatkan kepercayaan konsumen terhadap kegiatan, produk, atau jasa yang dilakukan oleh perusahaan atau institusi. Selain itu, pembentukan standar di atas peraturan perundang-undangan dibutuhkan untuk menghindari kombinasi instrumen yang duplikatif, sehingga tidak menjadi kontra produktif. ${ }^{49}$

Terakhir, sistem sertifikasi lingkungan sangat mengandalkan peran aktif aktor-aktor non pemerintah. Inisiatif untuk melakukan penaatan dilakukan atas dasar kesukarelaan setiap perusahaan atau institusi. Kemudian, proses sertifikasi atas suatu produk atau jasa juga selalu dilakukan oleh pihak ketiga, yakni lembaga sertifikasi yang bersifat independen..$^{50}$ Lembaga sertifikasi ini akan menilai apakah suatu produk atau jasa sudah memenuhi standar atau belum. Jika suatu produk atau jasa sudah memenuhi seluruh standar yang ditentukan, maka lembaga sertifikasi akan menerbitkan sertifikat bagi produk atau jasa tersebut. Lembaga sertifikasi ini pula yang akan mengawasi produk atau jasa yang telah mendapatkan sertifikat. Hal ini dapat mengurangi dominasi peran pemerintah sebagaimana yang ada pada pendekatan atur dan awasi dan instrumen ekonomi.

\section{Sertifikasi sebagai Upaya Mewujudkan Industri Minyak Kelapa Sawit Berkelanjutan}

Kampanye dan boikot konsumen yang terjadi di Perancis sebagaimana diuraikan dalam bagian Pendahuluan seyogyanya tidak ditanggapi dengan serta merta menghentikan produksi minyak kelapa sawit. Menghentikan produksi minyak kelapa sawit dan menggantinya dengan dengan minyak nabati lain justru akan menimbulkan dampak negatif yang lebih luas. Sebagai contoh, mengganti minyak kelapa sawit dengan minyak nabati lain, seperti minyak kedelai, rapeseed,

48 Soemarwoto, Atur Diri Sendiri: Paradigma Baru Pengelolaan Lingkungan Hidup, hlm. 109.

49 Dalam hal ini yang dimaksud dengan kombinasi instrumen yang duplikatif ialah kombinasi instrumen command and control yang menggunakan standar peraturan perundang-undangan dan instrumen sertifikasi sebagai instrumen penaatan hukum lingkungan sukarela. Lihat Neil Gunningham dan Darren Sinclair, "Designing Environmental Policy," dalam Smart Regulation Designing Environmental Policy, (Oxford: Oxford University Press, 2004), hlm. 432434.

50 Cora Dankers, Environmental and Social Standards, Certification and Labelling for Cash Crops, (Roma: Food and Agriculture Organization of the United Nations, 2003), hlm. 8. 
dan bunga matahari akan meningkatkan kebutuhan penggunaan lahan. Hal ini disebabkan rendahnya produktivitas tanaman-tanaman minyak nabati lain dibandingkan kelapa sawit. Sebagai contoh, 110 juta hektar tanaman kedelai hanya menghasilkan minyak sejumlah 47 juta ton, sedangkan 19 juta hektar area tanaman kelapa sawit mampu menghasilkan minyak sejumlah 62 juta ton. ${ }^{51}$ Kemudian, menghentikan konsumsi minyak kelapa sawit berarti menghentikan perkembangan industri produksi kelapa sawit. Industri produksi kelapa sawit memberikan banyak manfaat ekonomi bagi berbagai pihak. Jika industri produksi kelapa sawit dihentikan, maka akan ada jutaan rakyat yang akan kehilangan pekerjaan. Selain itu, negara produsen minyak kelapa sawit juga akan merugi dengan hilangnya devisa negara yang seyogiyanya dapat diperoleh dari ekspor minyak kelapa sawit. Menurut data yang diperoleh dari Direktorat Jenderal Perkebunan Kementerian Pertanian Repubik Indonesia, rata-rata nilai ekspor minyak kelapa sawit Indonesia dari tahun ke tahun terus mengalami kenaikan. ${ }^{52}$ Pada tahun 2016, nilai ekspor minyak kelapa sawit (Crude Palm Oil) mencapai 14.7 miliar US\$. ${ }^{53}$

Berdasarkan kondisi ini, dibutuhkan instrumen yang dapat mendorong penyelenggaraan produksi minyak kelapa sawit berkelanjutan, sehingga dapat menjawab atau menangkis kampanye-kampanye negatif terhadap produk minyak kelapa sawit. Terkait hal ini, sistem sertifikasi minyak kelapa sawit dianggap menjadi solusi yang paling tepat. Sertifikasi minyak kelapa sawit diharapkan dapat mendorong para pelaku industri minyak kelapa sawit untuk menerapkan prinsip dan kriteria minyak kelapa sawit berkelanjutan dalam setiap aktivitas industrinya. Bagi pelaku industri yang telah memenuhi prinsip dan kriteria minyak kelapa sawit berkelanjutan, maka akan mendapatkan sertifikat. Pemilikan sertifikat tersebut menjadi simbol atau bukti bahwa produksi minyak kelapa sawit telah dilakukan secara berkelanjutan. Hal ini yang diyakini dapat meningkatkan nilai dagang produk tersebut, membuka akses produk ke pasar yang lebih luas, dan menangkis kampanye negatif terhadap produksi minyak kelapa sawit. Dalam hal ini, konsumen dan berbagai organisasi lingkungan dan sosial memandang bahwa

51 Bungaran Saragih, Mitos versus Fakta Industri Minyak Sawit Indonesia dalam Isu Sosial, Ekonomi dan Lingkungan Global, hlm. 11.

52 Direktorat Jenderal Perkebunan Kementerian Pertanian Republik Indonesia, Statistik Perkebunan Indonesia 2015-2017, (Jakarta: Direktorat Jenderal Perkebunan, 2015), hlm. 5.

53 Ibid. 
produsen minyak kelapa sawit telah memenuhi tanggung jawab lingkungan dan sosialnya.

Sertifikasi RSPO merupakan sistem sertifikasi minyak kelapa sawit berkelanjutan yang bersifat global dan pertama kali diterapkan. Pembentukan RSPO berawal pada tahun 2001 ketika World Wildlife Fund for Nature (WWF) berupaya untuk membentuk wadah yang dapat mempertemukan berbagai pemangku kepentingan di industri minyak kelapa sawit. ${ }^{54}$ Para pemangku kepentingan tersebut meliputi produsen minyak kelapa sawit, pengolah atau penjual minyak kelapa sawit, produsen barang untuk konsumen (manufaktur), pedagang, bank dan investor, LSM di bidang lingkungan, dan LSM di bidang sosial. Setelah terbentuk, pada tahun 2007 RSPO meluncurkan instrumen sertifikasi RSPO. Sertifikasi RSPO ini bersifat sukarela, sehingga tidak ada paksaan bagi pelaku industri untuk memperoleh sertifikat RSPO. Pelaku industri yang mendapatkan sertifikat RSPO dapat menggunakan merek dagang atau logo RSPO pada produknya. Penggunaan logo ini menjadi simbol bahwa produksi minyak kelapa sawit telah dilakukan secara berkelanjutan. Hal ini diyakini dapat meningkatkan kredibilitas produk minyak kelapa sawit di mata konsumen. Sertifikasi RSPO juga dianggap dapat membuka akses minyak kelapa sawit ke pasar internasional.

Pada tahun 2011 Pemerintah Indonesia meluncurkan sistem sertifikasi minyak kelapa sawit berkelanjutan nasional yang diberi nama Sertifikasi ISPO. Pembentukan Sertifikasi ISPO merupakan bagian dari pelaksanaan kewajiban Pemerintah Indonesia untuk memelihara lingkungan, meningkatkan kegiatan ekonomi, sosial, dan penegakan peraturan perundang-undangan Indonesia di bidang perkelapa-sawitan. ${ }^{55}$ Selain itu, Sertifikasi ISPO dianggap lebih mencerminkan kepentingan nasional. ${ }^{56}$

54 Roundtable on Sustainable Palm Oil, "About Us," http://www.rspo.org/about, diakses tanggal 27 Maret 2017.

55 Indonesia, Menteri Pertanian, Peraturan Menteri Pertanian tentang Sistem Sertifikasi Kelapa Sawit Berkelanjutan Indonesia (Indonesian Sustainable Palm Oil Certification System / ISPO), Nomor PM 11 Tahun 2015, lampiran I, hlm. 9.

56 Ica Wulansari dan Ridzki R. Sigit, “Sawit Berkelanjutan: Antara Mencari Standard Sertifikasi dan Desakan Perubahan," http://www.mongabay.co.id/2016/03/18/sawit-berkelanjutanstandard-sertifikasi-dan-desakan-perubahan/, diakses tanggal 6 Juli 2017. 
Kepesertaan Sertifikasi ISPO bersifat wajib bagi perusahaan perkebunan dan bersifat sukarela bagi pekebun kelapa sawit. ${ }^{57}$ Penerapan kepesertaan Sertifikasi ISPO secara sukarela bagi pekebun kelapa sawit swadaya didasarkan masih terbatasnya kemampuan sebagian pelaku industri kelapa sawit Indonesia untuk memenuhi prinsip dan kriteria ISPO. Pada tahun 2020, Kementerian Pertanian menargetkan sistem sertifikasi ini dapat diterapkan secara wajib bagi seluruh pelaku industri kelapa sawit di Indonesia. ${ }^{58}$ Sistem sertifikasi ISPO merujuk pada prinsip dan kriteria ISPO yang disusun berdasarkan peraturan perundangundangan Indonesia.

Pada tahun2015, Pemerintah Malaysiajuga secara resmimeluncurkanSertifikasi MSPO. Sertifikasi MSPO ini diimplementasikan dan dikelola oleh Malaysian Palm Oil Certification Council (MPOCC). ${ }^{59}$ Sertifikasi MSPO ini merupakan upaya untuk memastikan bahwa minyak produksi kelapa sawit Malaysia telah diproduksi secara berkelanjutan berdasarkan standar MSPO. Pada awal pembentukannya, kepesertaan Sertifikasi MSPO bersifat sukarela, namun Pemerintah Malaysia telah mengumumkan bahwa Sertifikasi MSPO akan diterapkan secara wajib. Periode pemenuhan kewajiban untuk mendapat Sertifikat MSPO adalah paling lama tanggal 31 Desember 2018 bagi seluruh perusahaan minyak kelapa sawit di Malaysia yang telah memiliki Sertifikat RSPO dan paling lama tanggal 30 Juni 2019 bagi perusahaan yang tidak memiliki sertifikat RSPO. ${ }^{60}$ Bagi pekebun kelapa sawit skala kecil diberi tenggat waktu hingga tanggal 31 Desember 2019. ${ }^{61}$

Dari penjabaran tersebut, dapat diketahui bahwa Sertifikasi ISPO dan MSPO dirancang sebagai instrumen penaatan hukum lingkungan yang kepesertaannya bersifat wajib. Hal ini menjadikan Sertifikasi ISPO dan MSPO memiliki karakter

57 Indonesia, Menteri Pertanian, Peraturan Menteri Pertanian tentang Sistem Sertifikasi Kelapa Sawit Berkelanjutan Indonesia (Indonesian Sustainable Palm Oil Certification System / ISPO), Nomor PM 11 Tahun 2015, Ps. 2.

58 Kementerian Koordinator Bidang Perekonomian Republik Indonesia, "Siaran Pers: Pemerintah Siapkan Standar Kelapa Sawit Berkelanjutan," http://www.ekon.go.id/press/ view/siaran-pers-pemerintah.2490.html, diakses tanggal 1 Mei 2017.

59 Sanath Kumaran dan Harnarinder Singh, "Oil Palm Sustainability Standards in Malaysia and Peat Land Management," (makalah disampaikan pada International Peat Congress ke15, Sarawak, 15-19 Agustus 2016), hlm. 2.

60 Malaysian Palm Oil Council, "Malaysian Sustainable Palm Oil (MSPO) to Be Made Mandatory by 2019," http://www.mpoc.org.in/2017/03/30/malaysian-sustainable-palmoil-mspo-to-be-made-mandatory-by-2019/ diakses tanggal 8 Mei 2017.

61 Ibid. 
penaatan hukum lingkungan atur dan awasi. Hal inilah yang berpotensi menghambat Sertifikasi ISPO dan MSPO untuk mencapai upaya penaatan hukum lingkungan yang optimal. Untuk itu, sistem sertifikasi minyak kelapa sawit seyogyanya dibentuk sebagai instrumen penaatan hukum lingkungan sukarela. Hal ini bertujuan agar upaya penaatan hukum lingkungan melalui sertifikasi minyak kelapa sawit dapat menyerasikan hubungan pemerintah atau penyelenggara sistem sertifikasi dengan pelaku industri.

Terkait hal tersebut, pemerintah tidak lagi berperan dominan dengan mengandalkan paksaan yang disertai ancaman sanksi, namun mengandalkan partisipasi sukarela pelaku industri atas motivasi motivasi etik, motivasi kompetitif, dan motivasi relasi sebagaimana disinggung sebelumnnya. Hal ini diharapkan dapat mengatasi kelemahan utama pendekatan atur dan awasi yang menurut Prof. Otto Soemarwoto berlawanan dengan egoisme yang berakar di dalam diri manusia. ${ }^{62}$ Sertifikasi minyak kelapa sawit yang diterapkan sebagai instrumen sukarela diharapkan dapat mengurangi pola hubungan pemerintah versus pelaku industri, mengingat telah banyaknya instrumen atur dan awasi yang diterapkan bagi pelaku industri minyak kelapa sawit. Apabila pola hubungan ini dapat tercapai, diharapkan partisipasi pelaku industri minyak kelapa sawit terhadap sistem sertifikasi minyak kelapa sawit berkelanjutan dapat meningkat. ${ }^{63}$

Kemudian, salah satu fungsi utama sertifikasi ialah meningkatkan nilai dagang suatu kegiatan, produk atau jasa suatu perusahaan atau institusi. Sertifikasi menjadi petunjuk bahwa suatu produk atau jasa telah memenuhi standar-standar tertentu sebagai upaya melindungi lingkungan. Demi mendapatkan kepercayaan dari masyarakat, maka standar-standar yang dimuat pada umumnya lebih

62 Soemarwoto, Atur Diri Sendiri: Paradigma Baru Pengelolaan Lingkungan Hidup, hlm. 98.

63 Tingkat partisipasi dalam sistem sertifikasi minyak kelapa sawit berkelanjutan masih rendah. Hingga bulan Juni tahun 2015, baru 96 perusahaan perkebunan yang mendapat sertifikat ISPO dengan luas area perkebunan 756.743 hektar dan total produksi minyak kelapa sawit mentah sebesar 3,85 juta ton. Lihat: Rosediana Suharto, dkk. Studi Bersama Persamaan dan Perbedaan Sistem Sertifikasi ISPO dan RSPO, [Jakarta: s.n., 2015], hlm. 15. Jumlah tersebut masih jauh dibandingkan luas lahan perkebunan kelapa sawit di Indonesia yang mencapai 11 juta hektar dengan total produksi minyak kelapa sawit mentah mencapai 30 juta ton (Direktorat Jenderal Perkebunan, 2015). Hingga bulan Maret tahun 2017 total lahan perkebunan yang bersertifikat MSPO baru mencapai 245.599 hektar. Jumlah tersebut masih cukup jauh dari total luas area perkebunan kelapa sawit Malaysia yang hingga tahun 2016 telah mencapai 5,74 juta hektar. Lihat: Malaysian Palm Oil Board, “Area Summary," http:/ / bepi.mpob.gov. my/images/area/2016/Area_summary.pdf, diakses tanggal 8 Mei 2017. 
tinggi dari standar-standar yang ditentukan peraturan perundang-undangan (beyond compliance). ${ }^{64}$ Pada kondisi inilah sistem sertifikasi dapat optimal dalam meningkatkan kepercayaan konsumen terhadap kegiatan, produk, atau jasa yang dilakukan oleh perusahaan atau institusi. Selain itu, pembentukan standar di atas peraturan perundang-undangan dibutuhkan untuk menghindari kombinasi instrumen yang duplikatif, sehingga menjadi kontra produktif. ${ }^{65}$ Hal-hal tersebut yang diperlukan agar sertifikasi minyak kelapa sawit berkelanjutan dapat optimal sebagai instrumen penaatan hukum lingkungan.

Kendati demikian, sertifikasi minyak kelapa sawit berkelanjutan yang dibentuk sebagai instrumen sukarela, seperti Sertifikasi RSPO juga belum optimal sebagai instrumen penaatan hukum lingkungan. Sebagai contoh, terdapat persoalan terkait tingkat partisipasi peserta Sertifikasi RSPO yang masih rendah. Hingga bulan Maret tahun 2017, luas lahan perkebunan yang bersertifikat RSPO baru mencapai 2,5 juta Ha. ${ }^{66}$ Luas lahan tersebut bahkan hanya mencapai sekitar $22 \%$ luas lahan kelapa sawit yang ada di Indonesia.

Terkait hal ini, diperlukan suatu strategi dari pemerintah atau regulator untuk mengoptimalkan sertifikasi minyak kelapa sawit berkelanjutan sebagai instrumen penaatan hukum lingkungan sukarela, sekaligus memastikan tercapainya perlindungan lingkungan dalam kaitannya dengan aktivitas industri minyak kelapa sawit. Pemerintah atau regulator dapat menerapkan konsep regulasi responsif yang dikemukakan oleh Ian Ayres dan John Braithwaite. Contoh penerapan konsep regulasi responsif tersebut dapat tergambar melalui piramida strategi regulasi ${ }^{67}$ dan piramida penegakan hukum ${ }^{68}$ sebagai berikut:

64 Soemarwoto, Atur Diri Sendiri: Paradigma Baru Pengelolaan Lingkungan Hidup, hlm. 109.

65 Dalam hal ini yang dimaksud dengan kombinasi instrumen yang duplikatif ialah kombinasi instrumen command and control yang menggunakan standar peraturan perundang-undangan dan instrumen sertifikasi sebagai instrumen penaatan hukum lingkungan sukarela. Lihat Neil Gunningham dan Darren Sinclair, "Designing Environmental Policy," dalam Smart Regulation Designing Environmental Policy, (Oxford: Oxford University Press, 2004), hlm. 432434.

66 Roundtable on Sustainable Palm Oil, "Certified Growers," http://www.rspo.org/ certification/certified-growers, diakses tanggal 8 Mei 2017

67 Ian Ayres dan John Braithwaite, Responsive Regulation Transcending the Deregulation Debate, (New York: Oxford University Press, 1992), hlm. 39.

68 Ibid., hlm. 35. 

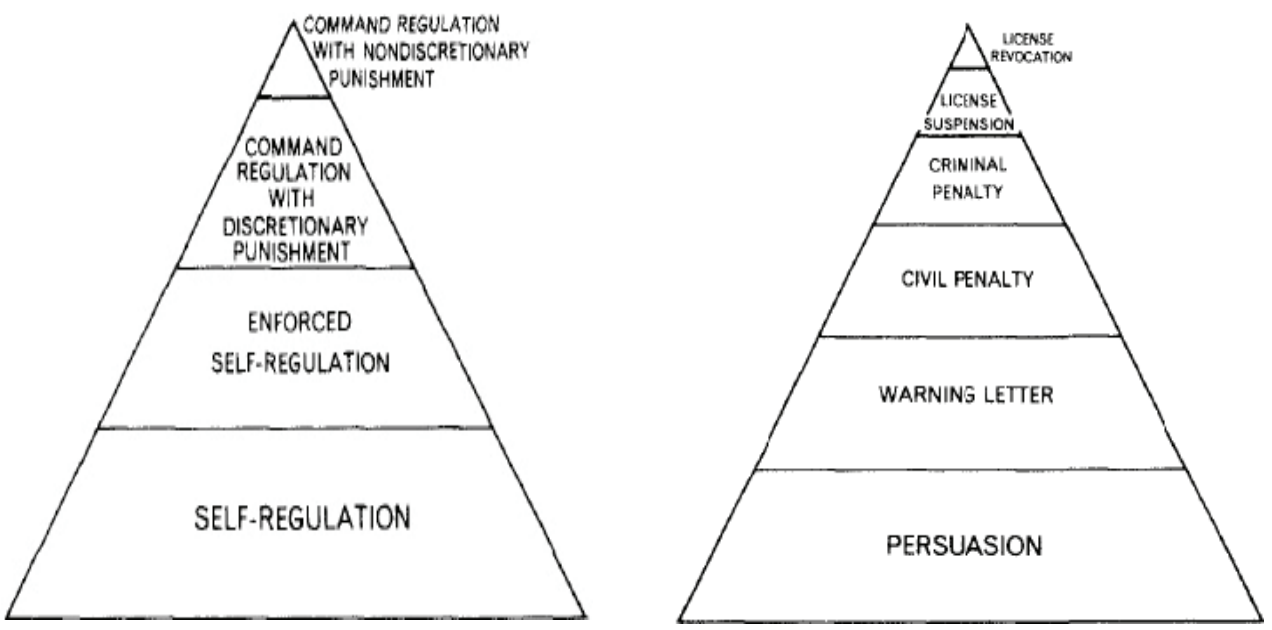

Gambar 4.1 Piramida Strategi Regulasi; Gambar 4.2 Piramida Penegakan Hukum

Secara sederhana, piramida tersebut menggambarkan hierarki strategi regulasi dan respon sanksi dari pemerintah terhadap pelaku industri atau individu berdasarkan perilakunya. Pada bagian dasar piramida, pemerintah membuka ruang bagi pelaku industri untuk mengatur dirinya sendiri. Pada tahap ini tidak ada paksaan dan sanksi. Pemerintah sekedar membujuk atau mengajak pelaku industri untuk bekerja sama. Selain itu, pemerintah juga telah menetapkan kondisi atau target pencapaian tertentu yang biasanya dituangkan dalam perizinan atau perjanjian. ${ }^{69}$ Apabila ekspektasi pemerintah tidak terpenuhi atau pelaku industri tidak melakukan penaatan sesuai batas standar yang ditetapkan pemerintah (peraturan perundang-undangan), maka pemerintah akan merespon ketidaktaatan tersebut dengan regulasi dan sanksi pada tingkatan yang lebih tinggi.

Regulasi dan sanksi pada tiap tingkatan di dua piramida tersebut tidak kaku. Ian Ayres dan John Braithwaite menyebutkan bahwa "this is (the Pyramid of Regulatory Strategies) just one example of the particular strategies that might be installed at different layers of the strategy pyramid [kalimat bercetak tebal merupakan tambahan dari penulis]."70 Begitu juga halnya dengan jenis sanksi pada piramida penegakan hukum yang mana jenis sanksinya dapat beragam tergantung lingkup wilayah pengaturan. ${ }^{71}$ Dalam kaitannya dengan pelaksanaan sistem sertifikasi

69 Mas Achmad Santosa, Good Governance \& Hukum Lingkungan, (Jakarta: ICEL, 2001), hlm. 260.

70 Ayres dan John Braithwaite, Responsive Regulation Transcending the Deregulation Debate, hlm. 38.

71 Ibid., hlm. 36. 
minyak kelapa sawit berkelanjutan, maka penerapan konsep regulasi responsif dapat tergambar melalui piramida berikut:
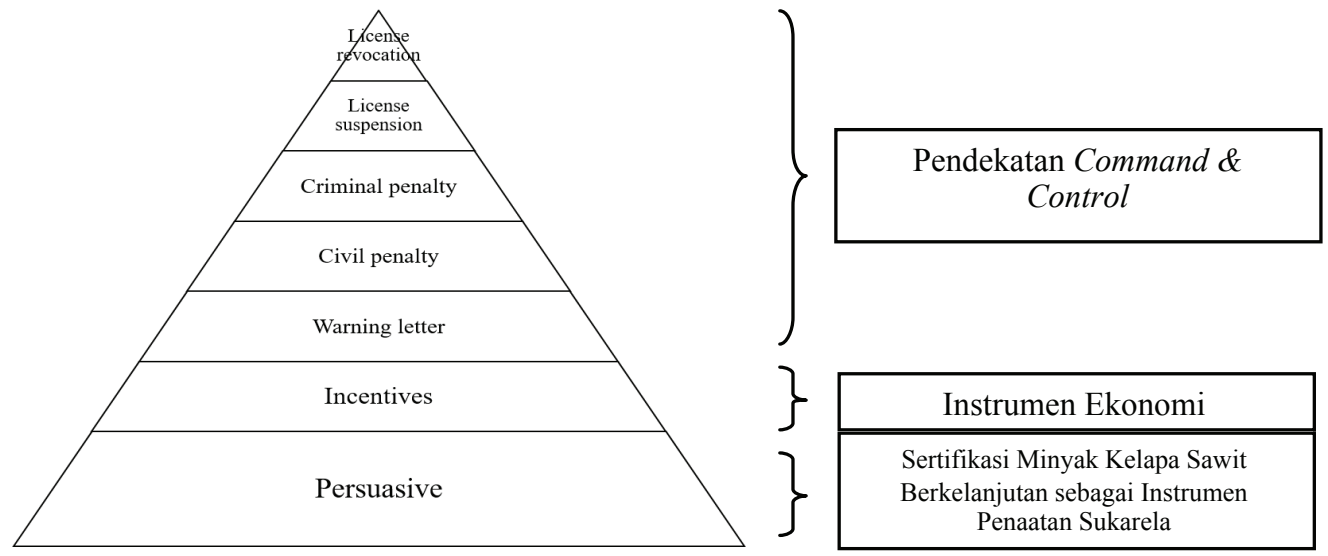

\section{Gambar 4.3 Piramida Penegakan Hukum Berdasar Konsep Regulasi Responsif dalam Pelaksanaan Sistem Sertifikasi Minyak Kelapa Sawit Berkelanjutan}

Pada dasar piramida, pemerintah menyelenggarakan sertifikasi minyak kelapa sawit berkelanjutan yang kepesertaannya bersifat sukarela. Dalam hal ini, pemerintah memberi ruang kepada pelaku industri minyak kelapa sawit untuk secara sukarela mencapai penaatan dengan memenuhi seluruh prinsip dan kriteria sertifikasi minyak kelapa sawit berkelanjutan. Pada tahap ini, pemerintah mendorong partisipasi pelaku industri dengan pendekatan persuasif, misalnya dengan mengajak pelaku industri terlibat dalam pembentukan prinsip dan standar sertifikasi dan pengembangan sistem sertifikasi. Kendati demikian, pemerintah telah terlebih dahulu memiliki standar yang tidak boleh dilewati atau dilanggar oleh pelaku industri, agar upaya perlindungan lingkungan dan sosial tetap terjamin. Standar tersebut merupakan standar yang ditentukan peraturan perundang-undangan yang biasanya berbentuk instrumen perizinan.

Sebagai instrumen penaatan hukum lingkungan yang kepesertaannya sukarela, prinsip dan kriteria sertifikasi minyak kelapa sawit berkelanjutan haruslah dibentuk lebih kuat atau di atas standar peraturan perundang-undangan (beyond compliance). Jika prinsip dan kriteria yang digunakan sama dengan standar yang ditentukan peraturan perundang-undangan, maka akan terdapat dua instrumen yang duplikatif, sehingga upaya penaatan hukum lingkungan menjadi 
kontra produktif. ${ }^{72}$

Pada tingkatan selanjutnya, pemerintah berupaya untuk mendorong partisipasi pelaku industri untuk memenuhi prinsip dan kriteria sistem sertifikasi dengan menyediakan insentif-insentif. Insentif tersebut dapat berupa bantuan dana atau finansial bagi pelaku industri untuk membantu pelaku industri memenuhi prinsip dan kriteria sistem sertifikasi yang sudah ditetapkan. Merujuk pada contoh-contoh yang diberikan oleh Al Iannuzzi, insentif juga dapat berupa mitigasi hukuman (penalty mitigation), prioritas pengawasan yang rendah (lowest inspection priority), dan pengakuan (recognition) sebagai a star company. ${ }^{73}$ Jika pelaku industri tetap tidak berpartisipasi dalam sistem sertifikasi minyak kelapa sawit berkelanjutan dan justru berperilaku tidak taat dengan melanggar standar yang ditentukan peraturan perundang-undangan, maka pemerintah akan merespon dengan sanksi yang lebih berat, yakni denda administratif (civil penalty). Jika kemudian masih terdapat ketidaktaatan, baru pemerintah akan meresponnya dengan sanksi pidana. Terakhir, pemerintah akan merespon dengan sanksi berupa penundaan izin usaha dan pencabutan izin usaha. Mas Achmad Santosa menyebut "penundaan dan pencabutan izin usaha merupakan tindakan pamungkas mengingat implikasi ekonomi seperti implikasi terhadap nasib para pekerja dan implikasi terhadap perekonomian daerah dan nasional pada umumnya."74

Kendati demikian, adanya hierarki instrumen command and control dalam piramida penegakan hukum berupa sanksi pidana, denda administratif, penangguhan sementara, hingga pencabutan izin seyogyanya tidak dipandang hierarkis secara mutlak karena masing-masingnya memiliki karakter dan fungsi yang berbeda. Penerapan salah satu instrument tidak menyebabkan instrumen lain menjadi gugur. Sebagai contoh, ketika pelaku usaha dikenakan sanksi pidana, maka terhadap pelaku usaha tersebut juga masih dapat dicabut izinnya.

Namun, penerapan konsep regulasi responsif seperti yang tergambar pada piramida strategi regulasi dan piramida penegakan hukum tersebut masih sangat

72 Lihat Neil Gunningham dan Darren Sinclair, "Designing Environmental Policy," dalam Smart Regulation Designing Environmental Policy, (Oxford: Oxford University Press, 2004), hlm. 432-434.

73 Alphonse Iannuzzi, Jr., Industry Self-Regulation and Voluntary Environmental Compliance, hlm. 168-170.

74 Santosa, Good Governance \& Hukum Lingkungan, hlm. 261 
terkonsentrasi pada hubungan dan interaksi antara pemerintah atau regulator dan pelaku industri. ${ }^{75}$ Untuk mengoptimalkan penyelenggaraan sistem sertifikasi minyak kelapa sawit berkelanjutan sebagai instrumen sukarela, sertifikasi minyak kelapa sawit berkelanjutan perlu didukung oleh peran aktif pihak ketiga. Terlebih, penyelenggaraan sistem sertifikasi minyak kelapa sawit berkelanjutan dilakukan untuk mendorong pelaku industri untuk mencapai penaatan di atas standar peraturan perundang-undangan (beyond compliance).

Mas Achmad Santosa menyebutkan "untuk mendorong dunia usaha memiliki proaktivisme lingkungan dengan pendekatan beyond compliance, sangat dipengaruhi oleh berbagai faktor eksternal dalam wujud tekanan (pressure)."76 Dalam hal ini:

"Paling tidak terdapat 6 (enam) jenis pressure yang memacu dunia usaha melakukan aktivitas beyond compliance: (1) Tekanan pemerintah dengan piranti penegakan hukum lingkungannya (melalui pendekatan command $\mathcal{E}$ control), (2) tekanan konsumen, (3) tekanan masyarakat, (4) tekanan pemegang saham, (5) tekanan dari pengecer dan pemasok (retailer dan supplier), dan (6) tekanan dari komunitas keuangan (financial community)."77

Sebagaimana diketahui, konsumen merupakan elemen terpenting bagi pelaku industri. Jika pelaku industri kehilangan konsumennya, maka keberlanjutan kegiatan usahanya akan terancam. Terkait hal ini, konsumen hanya akan mengonsumsi produk-produk yang diproduksi secara berkelanjutan. Tekanan bagi pelaku industri agar mencapai upaya penaatan beyond compliance juga dapat berasal dari elemen-elemen masyarakat, seperti LSM di bidang lingkungan dan sosial, serta komunitas-komunitas lokal.

Kemudian, diperlukan pula tekanan dari pemegang saham untuk mendorong perilaku ramah lingkungan oleh pelaku industri dengan menciptakan eco investing atau green invesment. Green investing mengindikasikan adanya investasi yang dilakukan dengan mempertimbangkan aspek lingkungan. Dalam hal ini, hal yang ingin dicapai dari green investing ialah meningkatkan kekayaan

75 Gunningham dan Darren Sinclair, “Designing Environmental Policy,” hlm. 397.

76 Ibid., hlm. 259.

77 Ibid. 
pribadi sembari menghindari kerugian bagi orang dan lingkungan. ${ }^{78}$ Terkait penyelenggaraan sistem sertifikasi minyak kelapa sawit berkelanjutan, investor hanya akan menginvestasikan uangnya pada perusahaan-perusahaan kelapa sawit yang tersertifikasi dan terbukti memiliki kinerja atau manajemen lingkungan terbaik. Terakhir, untuk menjamin bahwa produk yang dikonsumsi benar-benar berkelanjutan diperlukan juga tekanan dari pengecer dan pemasok. Hal ini untuk memastikan bahwa produk minyak kelapa sawit diproduksi secara berkelanjutan dari hulu hingga hilir industri kelapa sawit.

\section{Kesimpulan dan Saran}

Sertifikasi lingkungan merupakan instrumen penaatan hukum lingkungan sukarela. Sebagai instrumen penaatan hukum lingkungan sukarela, sertifikasi lingkungan mengandalkan kesukarelaan pelaku industri untuk mencapai penaatan di atas standar peraturan perundang-undangan (beyond compliance) atas motivasi etik yang berkaitan dengan adanya tanggung jawab lingkungan pelaku usaha, motivasi kompetitif yang muncul atas kepentingan pelaku usaha untuk memperoleh keuntungan dengan menerapkan praktik-praktik berkelanjutan, dan motivasi relasi yang bertujuan untuk mencapai legitimasi dan hubungan yang lebih baik dengan para pemangku kepentingan.

Pembentukan Sertifikasi ISPO dan MSPO sebagai instrumen penaatan hukum lingkungan belum optimal karena Sertifikasi ISPO dan MSPO dirancang sebagai instrumen dengan karakter atur dan awasi. Hal ini membuat Sertifikasi ISPO dan MSPO menjadi duplikatif dengan instrumen-instrumen command and control lain yang sudah ada, sehingga penerapan instrumen sertifikasi tersebut justru menjadi kontra produktif. Kendati demikian, Sertifikasi RSPO yang dibentuk sebagai instrumen penaatan hukum lingkungan sukarela juga belum mampu mengoptimalkan upaya penaatan hukum lingkungan di sektor industri minyak kelapa sawit. Hal ini disebabkan tidak adanya daya paksa dan kekosongan peran pemerintah dalam pengawasan dan pemberian insentif atas perilaku pelaku industri minyak kelapa sawit.

78 Rebecca Silver dan Kristin Underwood, “How to Go Green: Investing," https:/ /www.treehugger.com/htgg/how-to-go-green-investing.html, diakses tanggal 12 Juni 2017. 
Untuk itu, Pemerintah Indonesia dan Malaysia sebagai dua negara produsen minyak kelapa sawit terbesar seyogiyanya memperbaiki sertifikasi minyak kelapa sawit berkelanjutan sebagai instrumen penaatan hukum lingkungan sukarela. Dalam hal ini, sertifikasi yang dibentuk wajib memperhatikan aspekaspek keserasian hubungan pemerintah dan pelaku industri, partisipasi publik dan keterbukaan informasi yang memadai, prinsip dan kriteria sertifikasi yang mendorong penaatan di atas standar peraturan perundang-undangan (beyond compliance), kekuatan mengikat dan sanksi yang relevan, dan insentif untuk mendorong partisipasi pelaku usaha agar memperoleh sertifikat minyak kelapa sawit berkelanjutan.

Sebagai upaya untuk mengatasi kelemahan-kelemahan sertifikasi minyak kelapa sawit berkelanjutan sebagai instrumen penaatan hukum lingkungan sukarela, sertifikasi minyak kelapa sawit berkelanjutan perlu didukung atau dikaitkan dengan pendekatan command and control dan instrumen ekonomi. Kemudian, agar penyelenggaraan sistem sertifikasi minyak kelapa sawit berkelanjutan tersebut dapat lebih optimal dibutuhkan pula tekanan-tekanan dari pihak-pihak ketiga yang terdiri dari konsumen, masyarakat, pemegang saham, pengecer dan pemasok, dan komunitas keuangan. 


\section{Daftar Pustaka}

Achmad Santosa, Mas. (2001). Good Governance \& Hukum Lingkungan. Jakarta: ICEL.

Alm, Alvin L. (1992). A Need For New Approaches: Command-and-control is no longer a cure-all. EPA Journal, 18, 7-11.

Ayres, Ian dan John Braithwaite. (1992). Responsive Regulation Transcending the Deregulation Debate. New York: Oxford University Press.

Borkey, Peter, Matthieu Glachant, dan Francois Leveque. Voluntary Approaches for Environmental Policy in OEDC Countries: An Assessment. Centre d'economie Industrielle.

Chandra, Ardan Adhi. (2016). Petani Sawit Bisa Dapat Bantuan Rp 25 Juta/Hektar, Ini Syaratnya. Accessed on July 8, 2017 from https://finance.detik.com/ industri/3190634/ petani-sawit-bisa-dapat-bantuan-rp-25-jutahektar-inisyaratnya.

Ching, Ooi Tee. (2017). Gov't Assures Implementation of MSPO Certification Practical, Financial Aid for Smallholders. Accessed on July 8, 2017 from https:/ / www.nst.com.my/news/2017/02/215108/govt-assures-implementationmspo-certification-practical-financial-aid.

Dankers, Cora. (2003). Environmental and Social Standards, Certification and Labelling for Cash Crops. Roma: Food and Agriculture Organization of the United Nations.

Forest Watch Indonesia. (2017). Enam Tahun ISPO Kajian Terkait Penguatan Instrumen ISPO dalam Merespon Dampak-dampak Negatif Seperti Deforestasi, Kerusakan Ekosistem Gambut, Kebakaran Hutan dan Lahan, serta Konflik Tenurial. Bogor: Forest Watch Indonesia.

Gabungan Pengusaha Kelapa Sawit Indonesia. (2017). Industri Minyak Sawit Indonesia Merupakan Industri Strategis Nasional. Accessed on March 31, 2017 from https://gapki.id/industri-minyak-sawit-merupakan-industri-strategisnasional/\#more-1860. 
Gonzalez, Javier dan Oscar Gonzalez. (2005). An Analysis of the Relationship Between Environmental Motivations and ISO14001 Certification. British Journal of Management, 16, 133-148.

Gunningham, Neil dan Peter Grabosky. (2004). Smart Regulation Designing Environmental Policy. Oxford: Oxford University Press.

Hadjon, Philipus M. et al. (2011). Pengantar Hukum Administrasi Indonesia. Yogyakarta: Gadjah Mada University Press.

HR., Ridwan. (2014). Hukum Administrasi Negara. Jakarta: Rajawali Pers.

Indonesia, Menteri Pertanian. Peraturan Menteri Pertanian tentang Sistem Sertifikasi Kelapa Sawit Berkelanjutan Indonesia (Indonesian Sustainable Palm Oil Certification System / MSPO), Nomor PM 11 Tahun 2015.

International Organization for Standardization. Certification and Conformity Certification. Accessed on April 12, 2017 from https://www.iso.org/ certification.html.

Jr., Alphonse Iannuzzi. (2002). Industry Self-Regulation and Voluntary Environmental Compliance. Washington DC: Lewis Publishers.

Kementerian Koordinator Bidang Perekonomian Republik Indonesia. (2016). Siaran Pers: Pemerintah Siapkan Standar Kelapa Sawit Berkelanjutan. Accessed on May 1, 2017 from http://www.ekon.go.id/press/view/siaranpers-pemerintah.2490.html.

Malaysian Palm Oil Certification Council. Board of Trustees. Accessed on May 30, 2017 from https:/ / www.mpocc.org.my/board-of-trustees-mpocc.

Malaysian Palm Oil Certification Council. (2016). Stakeholder Consultation Requirements During Oil Palm Management Certification Audits for Certification Bodies Operating Oil Palm Management Certification Under The Malaysian Sustainable Palm Oil (MSPO) Certification Scheme (MSPO Document).

Mamudji, Sri. et al. (2005). Metode Penelitian dan Penulisan Hukum. Jakarta: Badan Penerbit Fakultas Hukum Universitas Indonesia. 
Mzoughi, Naoufel dan Gilles Grolleau. (2003). Voluntary Instrument for Environmental Management: a Critical Review of Definitions. Makalah disampaikan pada Annual Conference of Canadian Economic Association, Ottawa.

Parlemen Uni Eropa. Resolution 2222 (2016). 4 April 2017.

Roundtable on Sustainable Palm Oil. About. Accessed on March 27, 2017 from http://www.rspo.org/about.

Roundtable on Sustainable Palm Oil. (2016). RSPO Impact Report 2016. Accessed on April 27, 2017 from http://www.rspo.org/publications/download/ df716d24dd1ee80.

Roundtable on Sustainable Palm Oil. RSPO Smallholders Support Fund (RSSF). Accessed on June 7, 2017 from http://www.rspo.org/smallholders/rsposmallholders-support-fund.

Roundtable on Sustainable Palm Oil. (2017). RSPO Standard Operating Procedure for Standard Setting and Review (RSPO Document).

Saragih, Bungaran. (2016). Mitos versus Fakta Industri Minyak Sawit Indonesia dalam Isu Sosial, Ekonomi dan Lingkungan Global. Ed. 2. Bogor: PASPI.

Singh, Harnarinder dan Sanath Kumaran. (2016). Malaysian Palm Oil Certification Council's Role in The Implementation of The MSPO Certification Scheme." Makalah disampaikan pada Konferensi Minyak Kelapa Sawit Eropa, Warsaw.

Soekanto, Soerjono dan Sri Mamudji. (1979). Peranan dan Penggunaan Kepustakaan di dalam Penelitian Hukum. Jakarta: Pusat Dokumentasi UI.

Soekanto, Soerjono. (2006). Pengantar Penelitian Hukum. Cet. 3. Jakarta: UI-Press.

Soemarwoto, Otto. (2004). Atur Diri Sendiri: Paradigma Baru Pengelolaan Lingkungan Hidup. Yogyakarta: Gadjah Mada University Press.

Tempo. (2017). Sri Mulyani Minta Industri Sawit Sumbang Pendapatan Negara. Accessed on March 27, 2017 from https://m.tempo.co/read/ news/2017/02/02/090842383/sri-mulyani-minta-industri-sawit-sumbangpendapatan-negara. 
Wibisana, Andri G. (2016). Penaatan Hukum Lingkungan: Command and Control, Instrumen Ekonomi, dan Penaatan Sukarela. Draft Buku Hukum Lingkungan Indonesia.

Wibisana, Andri G. Pencegahan dan Pengendalian Pencemaran dan Kerusakan Lingkungan. Dalam Laode M. Syarif dan Andri G. Wibisana (Eds.), Hukum Lingkungan Teori, Legislasi dan Studi Kasus. [s.l.: s.n.].

Wulansari, Ica dan Ridzki R. Sigit. (2016). Sawit Berkelanjutan: Antara Mencari Standard Sertifikasi dan Desakan Perubahan. Accessed on July 6, 2017 from http:/ / www.mongabay.co.id/2016/03/18/ sawit-berkelanjutan-standardsertifikasi-dan-desakan-perubahan/. 